Published in final edited form as:

Crit Care Med. 2016 June ; 44(6): e447-e448. doi:10.1097/CCM.0000000000001744.

\title{
Response to the letter to Editor
}

Viranuj Sueblinvong, MD1 , Daniel W. Johnson, MD² $^{2}$, Gary L. Weinstein, MD,FCCP ${ }^{3}$, Michael J. Connor, MD ${ }^{1,4}$, Ian Crozier, MD ${ }^{5}$, Allison M. Liddell, MD ${ }^{6}$, Harold A. Franch, MD ${ }^{4}$, Bruce R. Wall, MD ${ }^{7}$, Andre C. Kalil, MD $^{8}$, Mark Feldman, MD $^{9}$, Steven J. Lisco, MD,FCCM ${ }^{2}$, and Jonathan E. Sevransky, MD,MHS,FCCM ${ }^{1}$

${ }^{1}$ Department of Medicine, Division of Pulmonary, Allergy, Critical Care and Sleep Medicine, Emory University School of Medicine, Atlanta, GA ${ }^{2}$ Department of Anesthesiology, Division of Critical Care, University of Nebraska Medical Center, Omaha, NE ${ }^{3}$ Department of Internal Medicine, Division of Pulmonary and Critical Care Medicine, Texas Health Presbyterian Hospital, Dallas, TX ${ }^{4}$ Department of Medicine, Division of Renal Medicine, Emory University School of Medicine, Atlanta, GA 5 Infectious Diseases Institute, Mulago Hospital Complex, Kampala, Uganda ${ }^{6}$ Department of Internal Medicine, Division of Infectious Diseases, Texas Health Presbyterian Hospital, Dallas, TX ${ }^{7}$ Department of Internal Medicine, Renal Section, Texas Health Presbyterian Hospital, Dallas, TX ${ }^{8}$ Department of Internal Medicine, Division of Infectious Diseases, University of Nebraska Medical Center, Omaha, NE ${ }^{9}$ Department of Internal Medicine, Texas Health Presbyterian Hospital, Dallas, TX

\section{Keywords}

Ebola virus disease; Critical care; sepsis

We thank Kissoon et al (1) for their interest in our manuscript, and appreciate the opportunity to concur with them about the importance of early recognition of patients with sepsis. We also applaud the work of the Global Sepsis Alliance, which has highlighted the prevalence of the syndrome, and the importance of early recognition of sepsis and has been working on improving patient outcomes.

The major advantage of early recognition of sepsis is that it allows for delivery of timely antibiotics, fluid resuscitation, and infection source control. It is not clear to us that this treatment paradigm fits patients with Ebola virus disease (EVD). While we have few autopsy studies to suggest the mechanism of death in EVD patients $(2,3)$, electrolyte replenishment and volume resuscitation seem to play an important role in early treatment for these patients who usually present with copious gastrointestinal volume loss (4). However, 2 out of 3 of our patients developed acute kidney injury without developing significant hypotension or generation of lactic acid, suggesting that renal injury occurs independent of hypoperfusion in EVD. While some have made assumptions that in resource rich countries treatment goals for critically ill EVD patients should align with treatment for sepsis patients with therapies such

Corresponding author: Viranuj Sueblinvong, MD, Emory University School of Medicine, ; Email: vsuebli@emory.edu Copyright form disclosures: The remaining authors have disclosed that they do not have any potential conflicts of interest. 
as lung protective mechanical ventilation, at this time this remains just an assumption. It has been shown that patients with EVD may exhibit abnormal immunologic, inflammatory and coagulation responses to bacterial infection $(3,5-7)$. For example, Ebola virus targets macrophage-rich lymphoid tissues, liver, and adrenal glands, which is distinct from bacterial sepsis $(5,6)$. Most importantly, early administration of broad-spectrum antimicrobials therapy has been shown to improve outcome in patients with bacterial-induced sepsis while at this time there is no proven antiviral therapy specific for patients with EVD (8).

Furthermore, there may be differences in treatment effects for therapies in resource poor compared with resource rich countries as shown in the FEAST Trial (Uganda, Kenya, Tanzania), and the simplified EDGT Trial (Zambia), both of which demonstrate the complexities and harms associated with broad treatment protocol generalizations $(8,9)$. At this time, while patients with EVD may meet both the old and proposed new sepsis definitions, we are concerned that "lumping" EVD patients into this broad category may minimize important clinical differences between patients with EVD and other life threatening infections. The under recognition of these significant biological and clinical differences discussed above could have detrimental implications for the treatment and prognosis of patients with EVD.

In conclusion, we agree that sepsis still remains under-recognized worldwide with a high mortality rate and continue educating healthcare providers is important. We disagree that labeling EVD as "sepsis" is crucial for these patients and applying the same treatment algorithm may negatively affect both patient care and clinical trial design.

\section{Acknowledgments}

Dr. Sueblinvong received support for article research from the National Institutes of Health (NIH). His institution received funding from the NIH. Dr. Weinstein is employed by Southwest Pulmonary Associates (The LLP he belongs to with his partners), provided expert testimony for various law firms (defense work), and lectured for GSK (Talks about COPD and Asthma meds). Dr. Connor, Jr received funding (Reimbursement for travel expenses to present at national meetings for presentations on the topic of Ebola), received an Honorarium for delivering lecture regarding critical care management of Ebola, and received funding from CR Bard. Dr. Wall disclosed government work and disclosed off-label product use (TKM Ebola). Dr. Sevransky disclosed other support (Stipend from Society for Critical Care Medicine for associate editor responsibilities).

\section{References}

1. Kissoon N, Daniels R, van der Poll T, et al. Sepsis- The Final Common Pathway To Death From Multiple Organ Failure In Infection. Crit Care Med. 2016 in press.

2. Martines RB, Ng DL, Greer PW, Rollin PE, Zaki SR. Tissue and cellular tropism, pathology and pathogenesis of ebola and marburg viruses. The Journal of pathology. 2015; 235(2):153-174. [PubMed: 25297522]

3. Singh G, Kumar A, Singh K, Kaur J. Ebola virus: An introduction and its pathology. Rev Med Virol. 2015

4. Chertow DS, Kleine C, Edwards JK, Scaini R, Giuliani R, Sprecher A. Ebola virus disease in west africa--clinical manifestations and management. The New England journal of medicine. 2014; 371(22):2054-2057. [PubMed: 25372854]

5. Falasca L, Agrati C, Petrosillo N, Di Caro A, Capobianchi MR, Ippolito G, Piacentini M. Molecular mechanisms of ebola virus pathogenesis: Focus on cell death. Cell Death Differ. 2015; 22(8):1250 1259. [PubMed: 26024394] 
6. Leung LW, Park MS, Martinez O, Valmas C, Lopez CB, Basler CF. Ebolavirus vp35 suppresses ifn production from conventional but not plasmacytoid dendritic cells. Immunology and cell biology. 2011; 89(7):792-802. [PubMed: 21263462]

7. Yen B, Mulder LC, Martinez O, Basler CF. Molecular basis for ebolavirus vp35 suppression of human dendritic cell maturation. Journal of virology. 2014; 88(21):12500-12510. [PubMed: 25142601]

8. Dellinger RP, Levy MM, Rhodes A, Annane D, Gerlach H, Opal SM, Sevransky JE, Sprung CL, Douglas IS, Jaeschke R, et al. Surviving sepsis campaign: International guidelines for management of severe sepsis and septic shock: 2012. Crit Care Med. 2013; 41(2):580-637. [PubMed: 23353941]

9. Maitland K, George EC, Evans JA, Kiguli S, Olupot-Olupot P, Akech SO, Opoka RO, Engoru C, Nyeko R, Mtove G, et al. Exploring mechanisms of excess mortality with early fluid resuscitation: Insights from the feast trial. BMC Med. 2013; 11:68. [PubMed: 23496872]

10. Maitland K, Kiguli S, Opoka RO, Engoru C, Olupot-Olupot P, Akech SO, Nyeko R, Mtove G, Reyburn H, Lang T, et al. Mortality after fluid bolus in african children with severe infection. N Engl J Med. 2011; 364(26):2483-2495. [PubMed: 21615299] 